\title{
Special book review
}

Lean and Mean: The Changing Landscape of Corporate Power in the Age of Flexibility by Bennett Harrison, Basic Books, New York, 1994.

The period of the mid-1970s through the mid-1980s was the decade of the small entrepreneur. The outcome was an entrepreneurial explosion during which small suddenly became more beautiful in the marketplace. During this period, entrepreneurship was everywhere, offering something new to governments, cities, corporations, and individuals [3, p. 16].

The new interest in entrepreneurship was not confined to the public and small business sectors. Many big business corporations in the United States and Europe were also exploring ways to elicit entrepreneurship within their structures. Soon, the rising belief in 'an entrepreneurial age' became synonymous with 'the down-sizing ear'. Hence, for more than a decade, the public has been told repeatedly that small firms are the engine of economic growth, while large corporations are in many respects becoming something of a dinosaur with bureaucratic organizations, and increasingly unable to compete in a post-industrial world.

Corporate giants once walked tall and proud, championing business development and economic growth across the globe. In the 1990s, big business is undergoing structural changes which have embraced the world of business and have caused the breakup of these mega-firms [1]. At the same time, no single factor, economic or demographic, is responsible for the changes sweeping through big businesses which have brought about this restructuring over the past decade. To some this is another episode of 'creative destruction', the fundamental impulse that sets and keeps the capitalist engine in motion as put forward by Joseph Schumpeter [5].

To others, including Bennett Harrison, 'the fall of big business' and 'the entrepreneurial explosion' of small businesses or the so-called 'wonderland economy' in the last decade represents a fundamental question: Is the large corporation indeed on the road to extinction as a viable, ecologically competitive form of business organization? Throughout the pages of Lean and Mean, Harrison, a professor of political economy in the H. John Heinz III School of Public Policy and Management at Carnegie Mellon University, is in search of an answer to this question. Furthermore, by answering this question the author tries to settle accounts with an emerging discourse concerning big firms, in which giant corporations are depicted as bureaucratic dinosaurs, remnants of an earlier economic age, unable to cope with the political and economic environment that scholars in different countries and disciplines have called the post-modern, post-fordist, or even post-industrial age [4, p. 8].

Lean and Mean begins with a discussion on the issue of concentration without centralization within the context of a new business landscape. Concentrated economic power is changing its shape, as big firms create various networks, alliances, and short as well as long-term financial and technological deals with one another, with government at all levels, and with legions of smaller firms which act as their suppliers and subcontractors.

While production is increasingly being decentralized, corporate managers are forced to enhance their flexibility in the face of mounting barriers within a changing environment. At the same time, the locus of ultimate power and control still remains within the largest institutions: multinational corporations, key governmental agencies, big banks and financial firms, and research hospitals. All that represents a fascinating issue. While big firms are strategically downsizing their structures, smaller firms are not experiencing a spectacular growth in terms of control over the economy. Rather, big firms still remain the central economic institution within the landscape of the new business environment.

Having a better position in the economy, big firms also still represent a better standard of living for their employees in comparison to smaller companies. In fact, reviewing the available data, Harrison argues that the part of the US economy which offers the lowest paid, least stable, and least well-protected job opportunities consists mainly of small businesses, especially in the service sector.

Altogether, the economic performance of small enterprises on average is inferior to that of large firms. Not only productivity levels and profit rates appear to be lower, but the capacity for innovation and techno- 
logical improvement also remains slimmer and thus, the average social standards, along with the quality of jobs and work conditions, are certainly inferior in the small-business sector, the wonderland economy.

Next, Lean and Mean turns to 'the myth of small firms as job creators'. Sometimes during the 1980s, economists, policy makers, business leaders, and management researchers in the United States were looking for answers as to why big firms in the 1970s and early 1980s were no longer the biggest employment providers even though they maintained their contribution to national income, output, and profit.

More importantly, this was happening while investment and productivity were stagnant during this period. Hence, the national response to this puzzle was given by 'the entrepreneurial explosion' of small businesses. Or, as an advocate of the wonderland economy has put it, "perhaps the most powerful tributary feeding the river of interest in entrepreneurship is the apparent intractability of a very depressing world economy" [6, p. 2].

The entrepreneurial explosion of small firms, as a response to the economic crisis of the 1970s-1980s, is usually explained by the following:

- vertical disintegration of the big firms, in order to escape unions;

- closures concentrated among the largest companies;

- a shift from manufacturing (with its generally larger facilities) to services (with its generally smaller structures);

- the strategic downsizing of large corporations as a part of a retreat-into-core competency; and

- a genuine disproportionate growth in the activity of smaller firms.

According to the author of Lean and Mean, business and economic research has found evidence for the first four explanations. However, the last one, the growth trend of small businesses, is what Harrison tries to address.

The myth of small firms as job creators was originated by the works of policy analyst David Birch who first tabulated this phenomenon over the threeyear intervals beginning in 1969 , in which he demonstrated that most jobs were created by small firms [2]. Soon, in Europe a similar attempt was launched by the Organization for European Cooperation and Development, and later supported by Gary Loveman and Werner Sengenberger's claim, highlighting small business growth since the end of WWII in nine European countries.
Reviewing a host of data in the US and Europe, the author of Lean and Mean came up with a different conclusion: from the early 1960s to the late 1980s, the number of jobs created by firms employing fewer than 100 employees did not change. Perhaps the major weakness of the advocates of 'the wonderland economy' is due to a lack of distinction between subsidiaries owned by big firms and genuine independent small companies. Within the subsidiaries owned by big firms, Lean and Mean reminds us, power, finance, and control remains in the hands of managers in charge of giant corporations.

In a word, Bennett Harrison scrutinizes the myth of entrepreneurial explosion because most advocates of 'the wonderland economy' have missed an important point: all data provided by Birch and OECD researchers shows that the lion's share of job creation over time is contributed by a tiny fraction of new firms. Put in another way, small firms are not the dominant job creators as previously claimed, even though units of production in factories, offices, stores, and corporate organizational structures are getting smaller.

Lean and Mean then sets the pace for another important question: "How is a firm's size related to its ability and propensity to innovate?" Traditionally, such a question is linked to an assumption concerning the role of small firms as technology leaders in business. Needless to say, Harrison refutes such a claim on three grounds. First, technical standards which make new innovations risky is often worth attempting only through an economy of size and scale. Second, commercializing new ideas requires access to an abundance of resources in terms of finance, research, market tests, and advertisement which is also linked to concentration and bigness. Third, economization of previous technological capabilities enables new technological innovations to benefit from a wealth of accumulated know-how.

Certainly these issues do not systematically privilege small businesses. For that, Harrison wonders if the small companies of the world do, in fact, have the capabilities to sustain themselves against today's multinational big firms. It is also clear that newly emerged industrial districts, such as Italy's EmiliaRomagna and Prato districts, are undergoing transformations away from the locally oriented, cooperative forms that once held the key to their success. As for the Silicon Valley, the computer and microelectronics capital of the America, Lean and Mean reminds us that this famous American industrial district was created and remains dependent on major multinational 
big firms, foreign investment, and vital institutions such as Stanford University and the Pentagon.

In this respect, Lean and Mean raises an important insight. In dealing with the problems and prospects of business revival, so many researchers, journalists, and policy makers have focused on the vision of a new wave of small firm-led economic growth. Moreover, such a view carries with it the danger of distracting us from the serious and difficult task of learning new ways to live with big firms and their vital role in our economic system.

At the same time, within the new socio-economic context, big firms are turning to flexible specialization. Due to the shakeout of weaker competitors and penetration of new technologies, it has been possible for companies to move physical and financial capital more rapidly from one place to another. As a result, an innovative managerial practice often known as flexible specialization, has created boundary spanning networks, linking together big and small companies operating in different industries, regions, and countries.

Furthermore, flexibility through reorganization and technological change has culminated into a new labormanagement relationship and into a reconfiguration of each firm's transactional and long-term relations with other companies. Indeed, the term flexibility has been given a more focused definition in the light of recent corporate restructuring which the term, as it applies to the strategic behavior of big firms, includes functional, wage, and numerical flexibility. What binds these three types of flexibility together is the creation of networks among producers.

According to Lean and Mean, a typology of classes of production networks is beginning to emerge from the observation of business practices around the world. First, craft-type networks in which work tends to be organized around specific projects rather than stable, sharply bounded firms. Second, small firmled industrial districts. Third, geographically clustered big firm-led production systems. Fourth, strategic alliances through which firms strive to span a manageable but diverse range of related activities and markets without having to undertake the full expense involved in actually building new plants or acquiring existing ones outright.

These networks may be driven by the globalization of knowledge but the developmental tendencies of networks is that of constant evolution. For instance, this is seen in the global expansion of organizations which constantly search for cheap labor and markets. However, in the future, Harrison predicts that networks will be formed around strong big firms.

The most formal and truly pragmatic examples of institutionalized cooperative competition through network forms of industrial organization are to be found in Japan. The Japanese models have given the rest of the world a vocabulary with which to understand how concentrated economic power can be reconciled with decentralized, cross-border production in ways that promote organizational learning, systematic innovation and flexibility in the face of competitive pressures. The Japanese word Keiretsu, meaning societies of business, is the best example of complex, networked production systems.

Europe and the United States are dealing differently with the Japanese case. Since the economic crisis of the 1970s, European corporations have sought to rationalize relationships with suppliers through licensing agreements, joint ventures, and more loosely coupled strategic alliances. The government has also played a continuing role in supporting the European evolution toward networked production systems.

In the U.S. a growing number of American firms are partnering with foreign companies and with one another, but the American economy has a long way to go in following through on the development of durable strategic alliances, and the other aspects of networking. In order to explain why many American companies still do not 'get it', Harrison mentions a number of issues such as seeking profitability by cutting costs, short-term planning, lack of assistance to their suppliers, short tenure with companies by managers, short-term accounting practices, and a myopic view of project analysis.

In conclusion, Harrison states that since corporations operate in a legal, political, cultural, and economic environment that is so fundamentally antagonistic to cooperation in economic behavior and bigness of their organizational structures, American corporate managers are caught in a very difficult situation. Be that as it may, in the brave new world of lean production, big firms are returning as the central economic institution vital for global competitiveness. While the wonderland economy still is appealing to many in business and academia, we are reminded about the forgotten needs of big firms and their subsequent evolution on a global landscape.

The author of Lean and Mean reaches his conclusions by analyzing a tremendous amount of economic data but, surprisingly has incorporated a writing style which is fresh and very readable. Indeed, Bennett 
Harrison's Lean and Mean is an important and valuable book not only to all business disciplines, but of great interest to management researchers in areas such as organizational policy and strategy as well as entrepreneurship.

\section{References}

[1] D. Bell, Downfall of the business giants, Dissent 40(3) (1993), 316-323.

[2] D. Birch, Job Creation in America, Free Press, New York, 1987.

[3] J. Case, The woderland economy, Inc., May 16, 1995, 14-29.

[4] B. Harrison, The return of the big firms, Social Policy 21(1) (1990), 7-19.

[5] J.A. Schumpeter, Creative destruction: the essence of capitalism, New Perspectives Quarterly 6(3) (1989), 10-11.
[6] A. Shapero, Why entrepreneurship? A worldwide perspective, Journal of Small Business Management 23(3) (1985), $1-5$

Omid Nodoushani University of New Haven

School of Business 300 Orange Ave.

West Haven, CT 06516-1999, USA Tel.: +12039316038

Patricia A. Nodoushani Barney School of Business \& Public Administration University of Hartford 200 Bloomfield Ave.

West Hartford, CT 06117, USA

Tel.: +1 8607684346 